\title{
SPATIAL VARIETY AND DISTRIBUTION OF TRADITIONAL MARKETS IN SURAKARTA AS POTENTIAL FACTORS IN IMPROVING SPATIAL-BASED MANAGEMENT
}

\author{
I. Aliyah ${ }^{a, b}$, B. Setioko ${ }^{c}$, W. Pradoto ${ }^{d}$ \\ a Doctoral Candidate of Architecture and Urbanism Program, Diponegoro University, Indonesia \\ ${ }^{b}$ Department of Urban and Regional Planning, Sebelas Maret University, Indonesia \\ c Department of Architecture, Faculty of Engineering, Diponegoro University, Indonesia \\ ${ }^{d}$ Department of Urban and Regional Planning, Diponegoro University, Indonesia
}

\section{Article Info:}

Received: 28 November 2016

in revised form: 8 February 2017

Accepted: 27 February 2017

Available Online: 27 March 2017

\section{Keywords:}

Mapping, traditional market, spatial variety and distribution of traditional market, spatial-based management

\section{Corresponding Author:}

Istijabatul Aliyah

Doctoral Program in Architecture

and Urbanism, Diponegoro

University, Indonesia

Email: aliyahuns@gmail.com

\begin{abstract}
Traditional markets function as trading place, socio-culture interaction, and recreation facility either in regional or urban scope. Distribution and variety of spatial condition influence traditional markets' planning both physically and non-physically. Therefore, this research aimed to conduct a mapping of traditional markets' spatial distribution and variety as potential factors to improve spatial-based management. Analysis methods including: (1) Mapping by employing Geographic Information System,

(2) Category Based Analysis (CBA), and (3) Interactive Analysis were applied in Surakarta City as the research location. The result of this research signifies that spatial variety and distribution of traditional markets in Surakarta had similar pattern between one market to others; overlapping service function; specific commodity types in accordance with the market's characteristics; diverse operating hours. Spatial variety and distribution could be potential factors to improve traditional market management as shopping service. This result was contrasted with Central Place Theory by Christaller and Næss \& Jensen's research finding stating that distance became a key factor influencing accessibility to a number of activity facilities. Therefore, distance toward the service center is not considered as the main factor in traditional market management. The main factor in managing and controlling traditional markets' development includes service function, commodity specification, and operating hour's flexibility.
\end{abstract}

Copyright (C) 2017 GJGP-UNDIP This open access article is distributed under Creative Commons Attribution (CC-BY-NC-SA) 4.0 International license.

How to cite (APA 6th Style):

Aliyah, I., Setioko, B., \& Pradoto, W. (2017). Spatial variety and distribution of traditional markets in Surakarta as potential factors in improving spatial-based management. Geoplanning: Journal of Geomatics and Planning, 4(1), 63-74. doi:10.14710/geoplanning.4.1.63-74

\section{INTRODUCTION}

Traditional Javanese cultures portray traditional market as an ever-existing part in spatial planning pattern in Javanese cities. As a part of components of a city, traditional market is former urban activities with quite dominant influence. The location of traditional market occupies a particular field or area with or without building used as a place where trading activities take place. At the market, the commodities' merchants and consumers come across at determined place and fixed time with certain interval (Jano \& Mainville, 2006). On the other hand, it can be said that traditional markets as a node of goods and service exchange regionally grew and developed to encourage various activities in a city (Sirait, 2006). Furthermore, traditional markets located in urban areas could be seen as a sub-system of larger economic system inducing an area of development and forming trading circuit cycle (Pamardhi, 1997).

Nevertheless, various available activities in traditional markets have not yet been clearly identified in the case of the precise spatial usage according to spatial formation concept. In addition, spaces related to diversity and activity networks as well as doer running the activities in traditional markets have not been elaborated in detail, both routine and temporary. In fact, service function, commodity specification and 
operating hours are fundamental in spatial usage allocation of traditional markets in cities, specifically in Surakarta.

The study on spatial distribution can be examined from various research findings that have been conducted. Taubenböck et al. (2017) suggested that Polycentricity is a concept which occurs in a city having more than one center in the conurbation. It refers to the spatial distribution of the work density on the city's sub-center. As revealed by Wang et al. (2016), the population density in a city might result in the increase of urban sprawl complexity, the increase of new cities, the development of infrastructure, and the improvement on trade function. In addition, the interaction process between the location of trade and residence becomes a basis for the establishment of multi-centers in metropolitan city influenced by monopolistic competition, scale economy, spatial cost, preference for variety, and product/service differentiations. As proposed by (Lee \& Roseman, 1997), the incoming independent migration was one of the triggers in population density in which it is spatially concentrated in the city center.

Furthermore, various appearing ethnics were present as a consequence of migration. Tan, Kwan, \& Chai, (2017) suggested that differences in minority and the majority ethnics could form a space-time pattern of daily activities which occur from these two ethnic groups. In the formation of spatial and temporal, ethnic culture has a more significant influence to minority ethnic rather than to majority one. This is due to the formation of spatial and temporal employing work division based on gender and daily religious activities. On the other hand, in the development of a city, Tang (2017) suggested a variety of planning strategies that should have been undertaken by the government. These planning strategies and developments could be in the form of network expansion of open space in a strategic location adjacent to the business zone in order to encourage private sector participation in marketing promotion.

Strategic location distribution can be examined by the method namely the zone-image-vision-based system employed by Pothen \& Nuske (2016). Afterwards, the image map analysis is conducted to predict the development of the zone. The result is a spatial prediction map as the database of targeting strategic zone. Different method was applied by Bae \& Yun (2017), in a research that spatial distribution approach can be carried out through analysis of geo-tag landscape photo collection as an effective tool for spatiotemporal distribution of landscape of a region. This can be done to determine the spatial distribution based on each activity and time. Related to the economic system, Yan (2008) revealed that the application of various types of pricing strategies is used for managing an economic business. Various models, pricing strategies, and market structure can employ some distribution networks for product marketing. Within a more micro scope, Schweizer (1984) explained that periodic market such as weekly market is a spatial distribution system of service facility of a region which is attached to permanent settlement.

The understanding of traditional markets packaged in modern atmosphere as shown in Dongdaemun Korea orientates not only as a commercial place but also a part of the realization of sellers' organization and social order forms of market users forming social structure accumulated from time to time into social strength (Kim, Lee, \& Ahn, 2004). Similar to India, middle class society's entrepreneurship aspiration and motivation of becomes the most important aspect. Demographic profile showed that Indian society is educated, part-time worker, and has independent strength to grow in fulfilling financial needs both as consumer and market doer (Javalgi \& Grossman, 2016). In Bangkok, the frequency of consumer to come back visiting traditional markets is determined by significant relationship between consumer's attitude towards the amount of price, seller's service, place's quality, and selling-buying behavior (Wongleedee, 2015). Meanwhile, in Denmark, the variable of urban facility placement influences an activity movement. Socio-economic and movement behavior factors also function in forming the movement pattern.

The distance from residence to city center is the key factor influencing accessibility towards a number of facilities providing places for activity (Næss \& Jensen, 2004). In line with Næss and Jensen finding, traditional markets at macro level in the scope of urban scope showed that the development or relocation of traditional markets can transform the field use, street pattern, movement and building pattern or type, circulation path distribution, and land utilization and would eventually influence the development of urban space formation (Karnajaya, 2002). On the other hand, traditional markets at micro level existing in Indonesia are not much different with that in Bangkok, signifying that service quality, increasing number of seller and consumer identification factors play a significant role to encourage development and trading activities improvement in traditional markets (Rahadi, 2012). It is strengthened by research findings which 
place traditional markets as a part of cultural products and urban public space, where urban society gathers and develop social relationship between them (Ekomadyo, 2012). Meanwhile, traditional markets could equally function as a node of goods and services exchange regionally which then grow and develop stimulating various activities inside a city (Sirait, 2006).

According to several research related to spatial distribution (Bae \& Yun, 2017; Lee \& Roseman, 1997; Ling \& Jin, 2010; Pothen \& Nuske, 2016; Schweizer, 1984; Tan et al., 2017; Tang, 2017; Taubenböck et al., 2017; Yan, 2008) it can be concluded that the distribution of spatial variety of an urban service facility can be a potential factor in urban development. In addition, according to the analysis on several researches (Ekomadyo, 2012; Javalgi \& Grossman, 2016; Karnajaya, 2002; Kim et al., 2004; Næss \& Jensen, 2004; Rahadi, 2012; Sirait, 2006; Wongleedee, 2015), it can be concluded that the understanding of traditional markets in Asia are not much different, that traditional markets functions not only as selling-buying venue but beyond, it is related to life conception and socio-cultural interaction as well as recreation facility in regional and urban scope.

In terms of urban scope, traditional markets are considered as one of economic facility functioning as city service center. Central Place Theory suggests on the spatial distribution of urban system. This pattern is perceived as a central place and market area. Central place functions primarily to supply goods and services to its surrounding population in selling various goods and services. Meanwhile, market area was an area where consumer goes from and to the central place (Christaller, 1966). On the other hand, traditional markets as one of city components are vital component in the case of location, historical values and 'specification' network of traditional markets in Surakarta. As a matter of fact, related researches concerning on the mapping of traditional markets' spatial variety and distribution as potential factors in spatial-based management have not yet been revealed in detail. The previous theories and research findings have not focused on discussion in terms of how the mapping of traditional markets' spatial variety and distribution as potential factors to improve spatial-based management in Surakarta. The rare information on traditional markets' spatial variety and distribution for all related parties is indeed unfortunate. Therefore, this research attempts to give knowledge contribution by examining the mapping of traditional markets' spatial variety and distribution as potential factors to improve spatial-based management in Surakarta.

\section{DATA AND METHODS}

\subsection{Data}

In the trade sector, Surakarta is a city possessing potential to develop, as can be seen from the 43 existing traditional markets. Traditional markets in Surakarta have diverse width between one another. The characteristics of traditional markets from each sub-district, of which distribution is shown in Figure 1, can be explained as follow: (a) In the case of traditional market distribution, Banjarsari and Pasar Kliwon subdistricts had equal distribution from class I A to III A, while Laweyan sub-district is dominated by middle class traditional markets from I B to II B. (b) Serengan sub-district had the least number of traditional markets, two markets from class I A and I B ( $5 \%$ of the total population of traditional market). (c) Jebres and Banjarsari sub-districts had the same percentage in terms of the total number of traditional market (28 $\%$ of the total population of traditional market). In particular, there were 43 traditional markets in Surakarta of which class and address is shown in Table 1. Based on Table 1, it can be known the class and address of each market to obtain an early picture of traditional market distribution. Market class is determined by the area width and the number of sellers.

\subsection{Methods}

This research was conducted in the city of Surakarta considering the existing potential and problem in Surakarta, particularly related to the mapping of traditional markets' spatial variety and distribution as potential factors to improve spatial-based management in Surakarta. The research was carried out by collecting spatial data of traditional markets with the mapping of every market by employing Geograpic Information System (GIS) method. The mapping result obtained from each market was then compiled in Surakarta's map to acquire the whole picture in city's constellation. Spatial data was analyzed by applying Category Based Analysis (CBA) to classify the type of commodity, operating hours, and service scope. This 
classification will produce an overlap of each market in terms of the type of commodity, operating hours, and service scope. The classification result of traditional markets was then examined by employing Interactive Analysis Method to obtain relationship between markets related to service function, commodity specification, and operating hour's flexibility.

In this research, purposive sampling was used to emphasize on three aspects, namely commodity type, operating hours, and service scope. Besides, collecting data was conducted by applying snowball technique to determine informants by contacting the first key person from user society, sellers and government staffs as well as private institution selected and searching for the next key people from the information of the first key people and so on until the data required are fulfilled. Meanwhile, the data validity in this research was undertaken by employing respondent source of data triangulation from the users of traditional markets and data collection technique triangulation by member checking.

Figure 1. The map of traditional market distribution in Surakarta (Modified from Aliyah, Setioko, \& Pradoto, 2016)

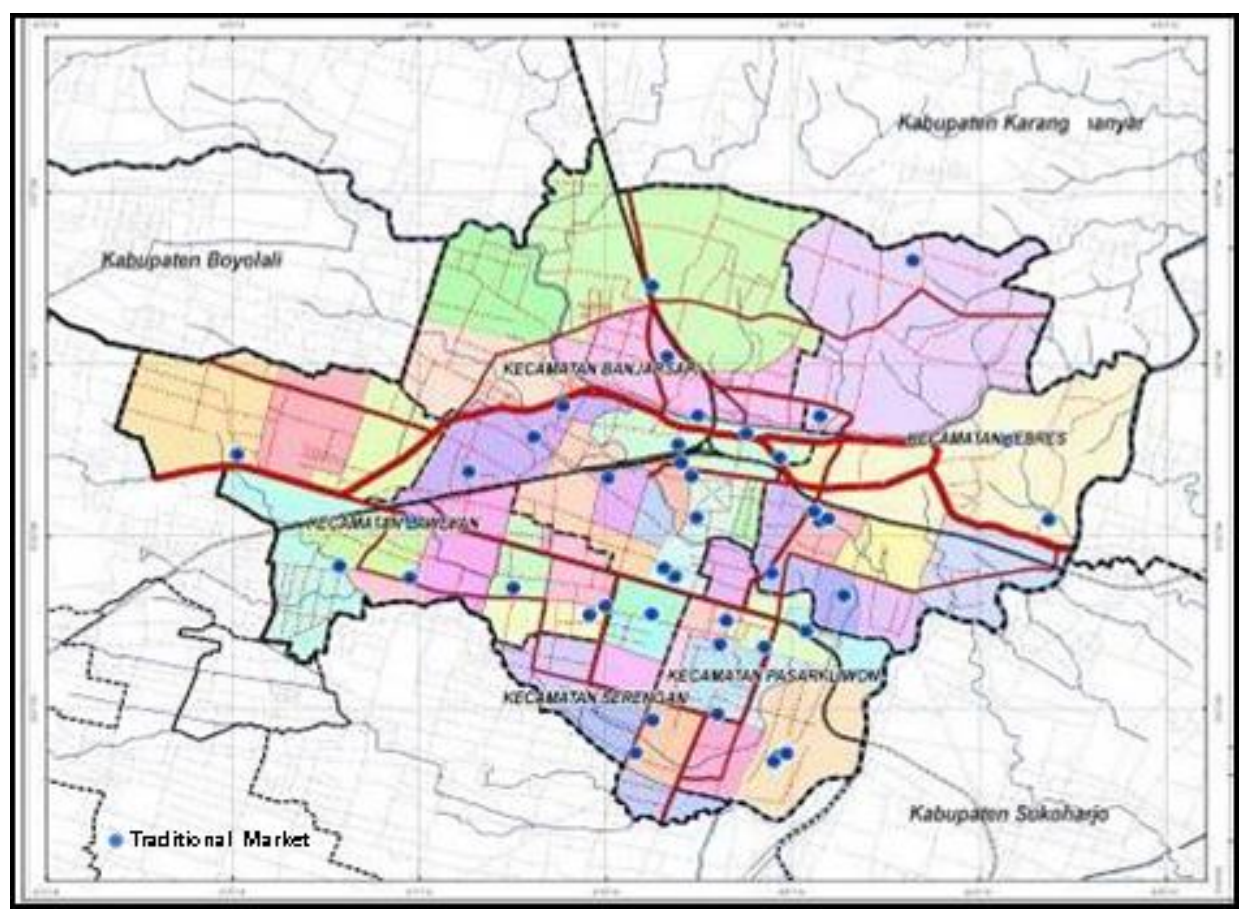

Table 1. Class and address of traditional markets in Surakarta (The Agency of Market Management and researcher's analysis, 2015)

\begin{tabular}{|c|c|c|c|c|c|}
\hline \multirow[t]{2}{*}{ No } & \multirow[t]{2}{*}{ MARKET } & \multirow[t]{2}{*}{ CLASS } & \multicolumn{3}{|c|}{ MARKET'S ADDRESS } \\
\hline & & & STREET & VILLAGE & SUB-DISTRICT \\
\hline 1 & LEGI & I A & Jl. Jend. S Parman & Setabelan & Banjarsari \\
\hline 2 & KLEWER & I A & Jl. Dr. Rajiman & Gajahan & Pasar Kliwon \\
\hline 3 & SINGOSAREN & IA & Jl. Gatot Subroto & Kemlayan & Serengan \\
\hline 4 & GEDHE & I A & Jl. Jend Urip Sumoharjo & Sudiroprajan & Jebres \\
\hline 5 & NUSUKAN & IA & Jl. Kapten P Tendean & Nusukan & Banjarsari \\
\hline 6 & NONGKO & I A & Jl. RM. Said & Mangkubumen & Banjarsari \\
\hline 7 & HARJODAKSINO & I B & Jl. Kom. Yos Sudarso & Danukusuman & Serengan \\
\hline 8 & JONGKE & I B & Jl. Dr. Rajiman & Pajang & Laweyan \\
\hline 9 & NOTOHARJO & I B & Jl. Serang, Semanggi & Semanggi & Pasar Kliwon \\
\hline 10 & TAMAN PASAR BURUNG \& IKAN HIAS & I B & Jl. Balekambang Lor & Manahan & Banjarsari \\
\hline 11 & GADING & II A & Jl. Veteran & Baluwarti & Pasar Kliwon \\
\hline 12 & REJOSARI & II A & Jl. Sindutan & Jebres & Jebres \\
\hline 13 & PUCANGSAWIT & II A & Jl. Ir. Juanda & Pucangsawit & Jebres \\
\hline 14 & PURWOSARI & II A & Jl. Brigjen Slamet Riyadi & Purwosari & Laweyan \\
\hline 15 & PANGGUNGREJO & II A & Jl. Panggungrejo & Jebres & Jebres \\
\hline 16 & NGARSOPURO & II A & Jl. Ronggowarsito & Timuran & Banjarsari \\
\hline 17 & SIDODADI & II A & JI. Brigjen Slamet Riyadi & Karangasem & Laweyan \\
\hline
\end{tabular}




\begin{tabular}{|c|c|c|c|c|c|}
\hline \multirow[t]{2}{*}{ No } & \multirow[t]{2}{*}{ MARKET } & \multirow[t]{2}{*}{ CLASS } & \multicolumn{3}{|c|}{ MARKET'S ADDRESS } \\
\hline & & & STREET & VILLAGE & SUB-DISTRICT \\
\hline 18 & CINDERAMATA & II A & Barat Alun Alun Utara & Kauman & Pasar Kliwon \\
\hline 19 & AYUBALAPAN & II A & Jl. Mongonsidi & Kestalan & Banjarsari \\
\hline 20 & MOJOSONGO & II A & Jl. Brigjen. Katamso & Mojosongo & Jebres \\
\hline 21 & LEDOKSARI & II A & Jl.Jend. Urip Sumoharjo & Jebres & Jebres \\
\hline 22 & KADIPOLO & II A & Jl. Dr. Rajiman & Panularan & Laweyan \\
\hline 23 & TANGGUL & II B & Jl. RE Martadinata & Kampungsewu & Jebres \\
\hline 24 & KABANGAN & II B & Jl. Dr. Rajiman & Sondakan & Laweyan \\
\hline 25 & PENUMPING & II B & Jl. Sutowijaya & Penumping & Laweyan \\
\hline 26 & AYAM & II B & Jl. Serang,Semanggi & Semanggi & Pasar Kliwon \\
\hline 27 & KLIWON & II B & Jl. Kapten Mulyadi & Kedunglumbu & Pasar Kliwon \\
\hline 28 & JEBRES & II B & Jl.Prof. B. Z. Yohanes & Jebres & Jebres \\
\hline 29 & KEMBANG & II B & Jl. Dr. Rajiman & Sriwedari & Laweyan \\
\hline 30 & MEBEL & II B & Jl. A. Yani & Gilingan & Jebres \\
\hline 31 & TRIWINDU & II B & Jl. Seram, Keprabon & Keprabon & Banjarsari \\
\hline 32 & NGEMPLAK & III A & Jl. A. Yani & Gilingan & Jebres \\
\hline 33 & BANGUNHARJO & III A & Jl. K. S. Tubun & Manahan & Banjarsari \\
\hline 34 & SIDOMULYO & III A & Jl. S. Parman & Gilingan & Banjarsari \\
\hline 35 & ELPABES & III A & JI. E. Saleh & Setabelan & Banjarsari \\
\hline 36 & SANGKRAH & III A & Barat Stasiun KA. Sangkrah & Sangkrah & Pasar Kliwon \\
\hline 37 & TUNGGULSARI & III A & Jl. Untung Suropati & Semanggi & Pasar Kliwon \\
\hline 38 & JURUG & III A & Jl. KH. Maskur & Jebres & Jebres \\
\hline 39 & MOJOSONGO P & III B & Jl. Sibela, Mojosongo & Mojosongo & Jebres \\
\hline 40 & NGUMBUL & III B & Jl. RM. said & Manahan & Banjarsari \\
\hline 41 & BAMBU & III B & $\begin{array}{l}\text { Jl. Tentara Genie Pelajar } \\
\text { Nusukan }\end{array}$ & NUsukan & Banjarsari \\
\hline 42 & BESI & III B & Jl. Serang,Semanggi & Semanggi & Pasar Kliwon \\
\hline 43 & JOGLO & III B & Jl. Kol. Sugiyono, Kadipiro & Kadipiro & Banjarsari \\
\hline
\end{tabular}

\section{RESULTS AND DISCUSSION}

Traditional markets in Surakarta as a city component have various commodities, operating hours, and service scope. The mapping result signified that the existence of traditional market in urban space occupies adjacent location and even does not consider the distance between markets. In fact, this condition has no influence on the market's development in attracting consumers and providing commodities. It is in accordance with what take place in Bangkok. Wongleedee (2015) suggested that the frequency of traditional market's consumers is determined by the significant relationship between the consumer's attitude toward the amount of price, seller's service, place's quality, and selling-buying behavior. It shows that distance is not the main factor for consumer's choice to visit traditional market. It is in contrast with Central Place Theory which explained about the spatial distribution of urban system (Christaller, 1966). Eisner, Gallion, \& Eisner (1993) highlighted that urban activity movement demands the presence of space and access which are connected one another. The diversity of existing activity within a traditional market will bring other supporting activities and eventually creates spatial function which always develops. Besides, in urban area, the activity diversity is accompanied with the development of trade, transportation, goods and service provision or the combination of all those activities.

The analysis resulted discussions connected to spatial distribution, commodity variety, and management improvement of traditional markets in Surakarta. These three elements are related between one and another. In this case, the distribution of traditional markets showing overlapping service and commodity variety can indicate the specification possessed by market. In addition, the management improvement explains that all parties related to traditional markets have strong attention toward traditional markets, which can be elaborated in detail as follows:

\subsection{Spatial Distribution of Traditional Markets in Surakarta}

The mapping of traditional markets' distribution started by identifying the distribution of traditional market location in Surakarta. Identification was undertaken towards 43 units of traditional market by collecting data of each unit, with is group based on the sub-district area. Surakarta has 5 sub-districts, as 
showed in Figure 2, 3, 4, 5, and 6. The mapping result showed that the distribution of traditional market in each sub-district region in Surakarta is not equal. Based on the distribution of traditional markets in all subdistricts, it can be known that the distribution's structure is as shown in Figure 7 and Table 2. The subdistrict having the biggest number of traditional markets is Banjarsari Sub-district that is 14 units in total or 32.6 percent of all existing traditional markets in Surakarta. On the other hand, the sub-district having the least number of traditional markets is Serengan Sub-district with 2 units or 4.7 percent of all existing traditional markets in Surakarta.

Figure 2. The map of traditional market area in Banjarsari Subdistrict (Analysis, 2016)
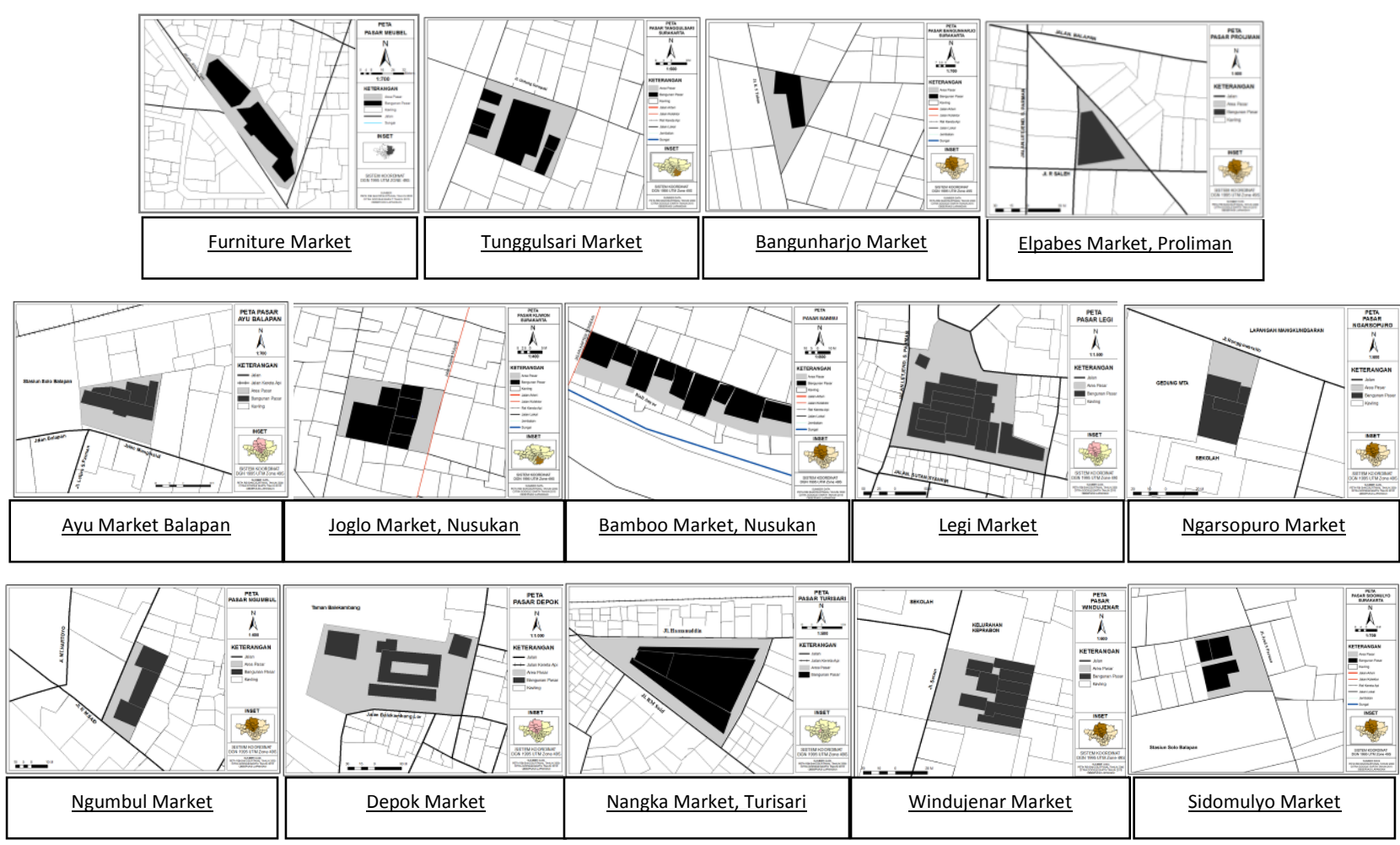

: Traditional Markets Building

Figure 3. The map of traditional market area in Pasar Kliwon Subdistrict (Analysis, 2016)

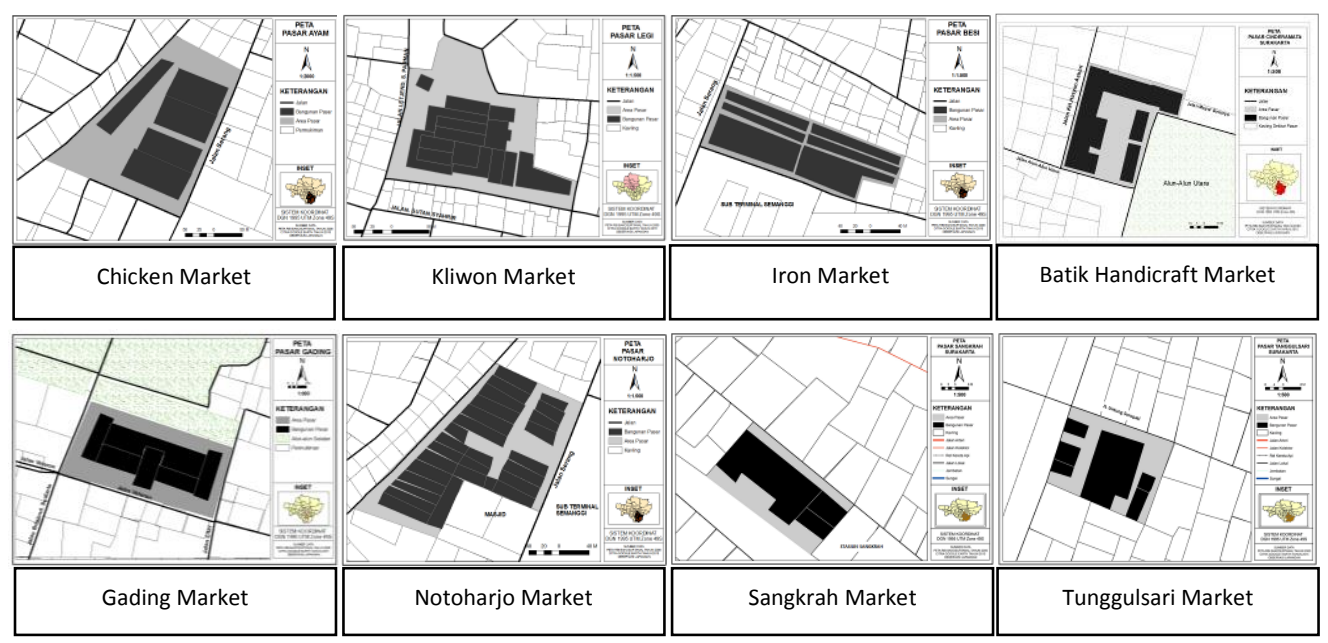

: Traditional Markets Building 
Figure 4. The map of traditional market area in Jebres Subdistrict (Analysis, 2016)

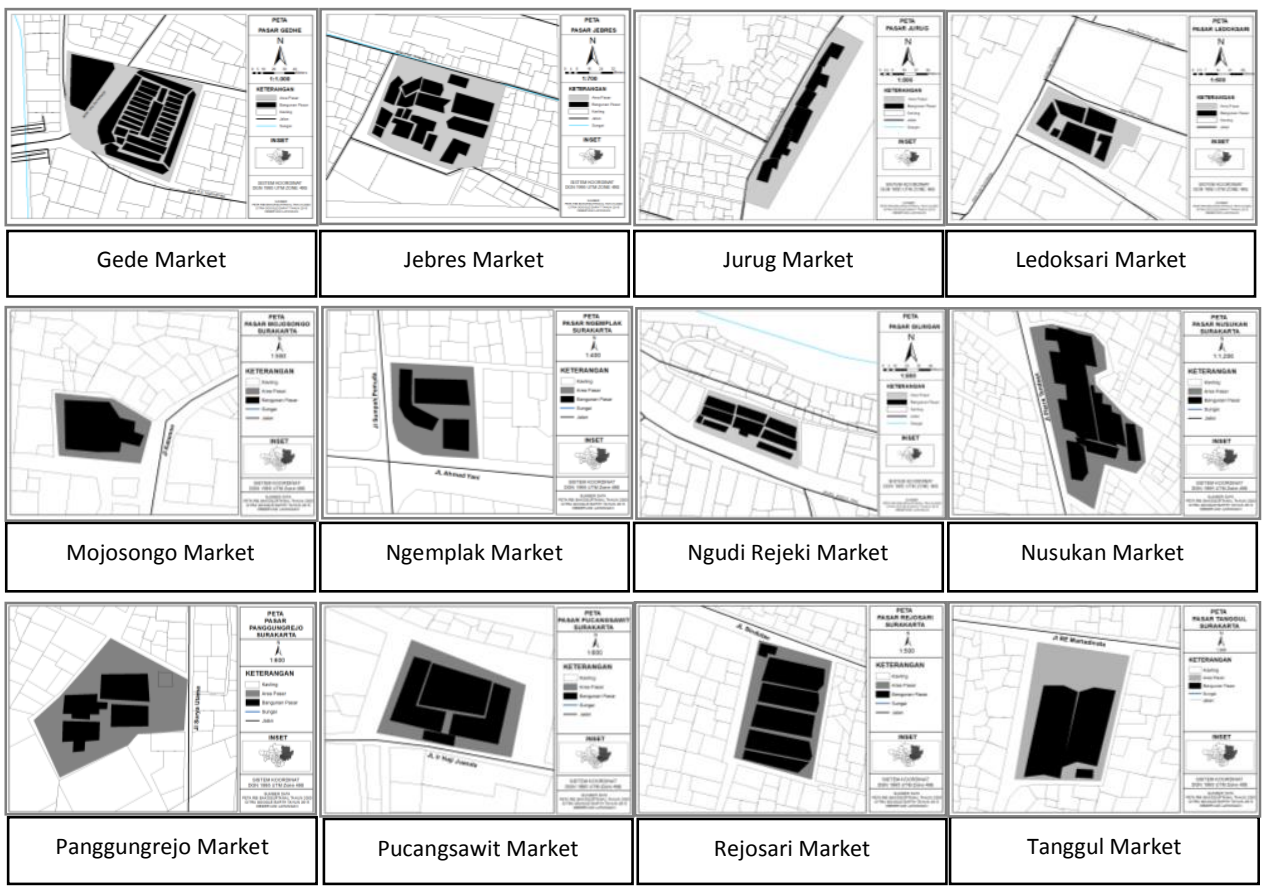

: Traditional Markets Building

Figure 5. The map of traditional market area in Laweyan Subdistrict (Analysis, 2016)

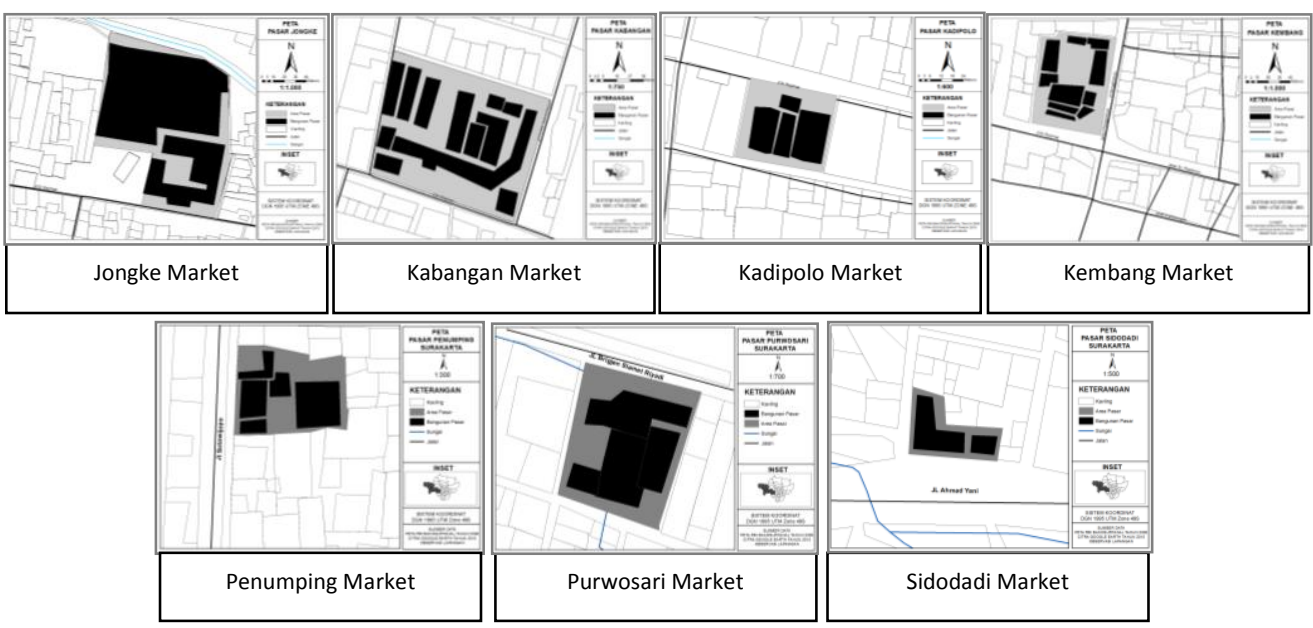

: Traditional Markets Building

Figure 6. The map of traditional market area in Serengan Subdistrict (Analysis, 2015)

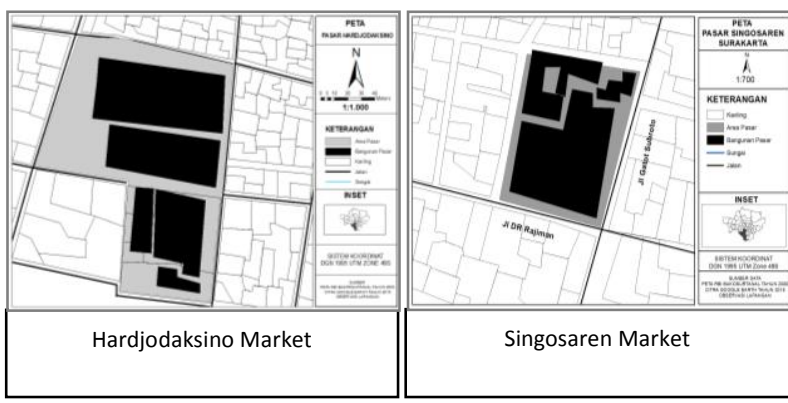

: Traditional Markets Building 
The mapping result of each traditional market unit can be compiled in Surakarta's constellation as shown in Figure 7 and Table 2. This mapping portrays diverse position and quantity of each subdistrict region. Therefore, it can be said that the distribution of traditional market in Surakarta is not based on the service standard and unit quantity as suggested by Central Place Theory by Christaller (1966). In fact, the real condition in Surakarta also shows different result from the research finding of Næss and Jensen (2004) stating that distance from settlement to city centre is the key factor influencing accessability to go to a number of facilities providing activities. Empirically, traditional markets in Surakarta have uniqueness in the distribution of location and the number of markets which is based on the consideration of society interest to choose commodity specification sold in traditional markets and based on natural growth of society needs. It is also in accordance with the research finding of Yu \& Nguyen (2015) that the distribution of traditional markets can be an implementation of the consumers and their service centre relationship management concept, moreover, social and cultural aspects influence consumer's perception.

Spatially, the distribution of traditional market in Surakarta is conceptually different with what happens in several cities (Bae \& Yun, 2017; Lee \& Roseman, 1997; Ling \& Jin, 2010; Pothen \& Nuske, 2016; Schweizer, 1984; Tan, Kwan, \& Chai, 2017; Tang, 2017; Taubenböck et al., 2017; Yan, 2008) It is because the spatial distribution of traditional market in Surakarta depends on society needs, commodity specification, and operational scope which differ between one to another market, as well as the existence of kinship sense growing between sellers and visitors.

Figure 7. The mapping of traditional market's distribution in Surakarta (Analysis, 2016)

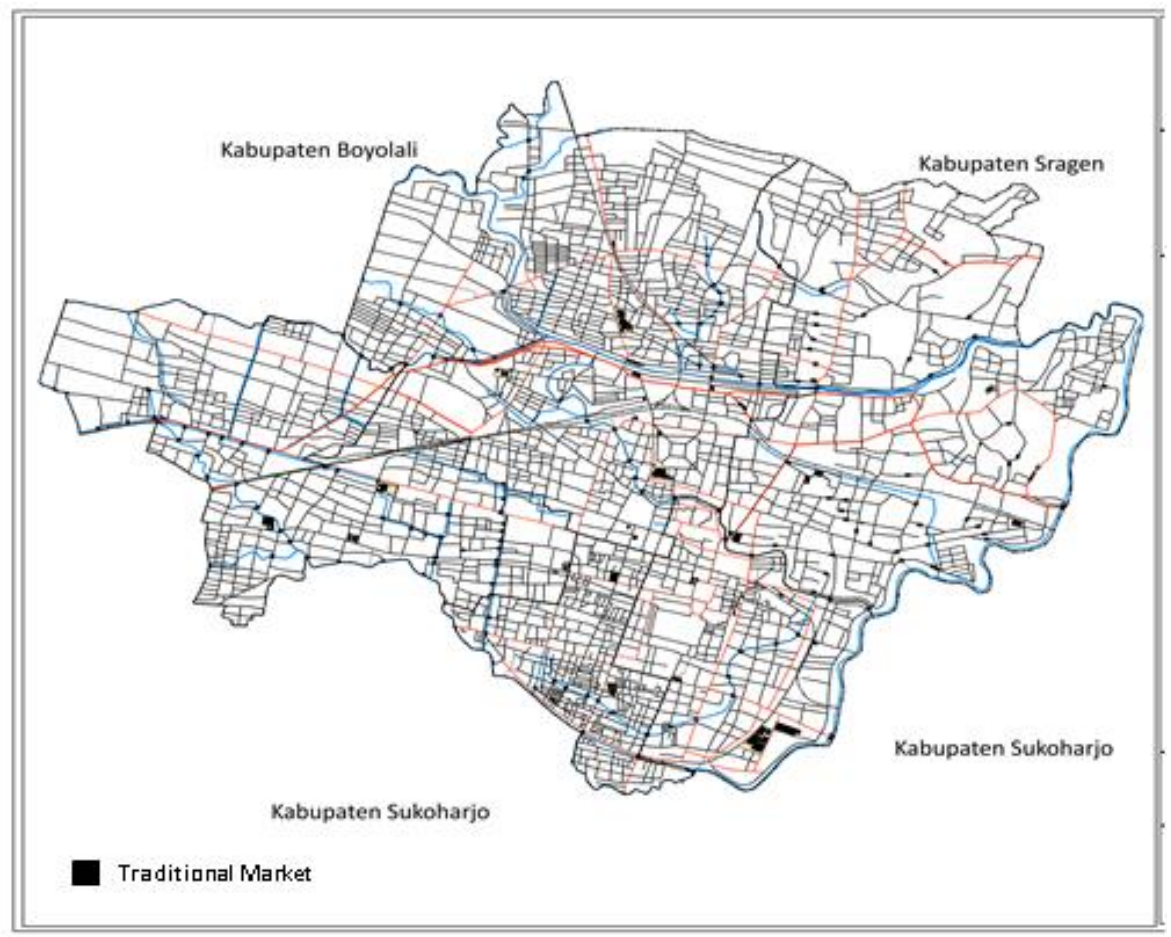

Table 2. The structure of traditional market's distribution in Surakarta (Analysis, 2016)

\begin{tabular}{rlrrr}
\hline No & \multicolumn{1}{c}{ Subdistrict } & Amount & Percentage (\%) & 16.3 \\
\hline 1. & Laweyan & 7 & 4.7 \\
\hline 2. & Serengan & 2 & 18.6 \\
\hline 3. & Pasar Kliwon & 8 & 27.8 \\
\hline 4. & Jebres & 12 & 32.6 \\
\hline 5. & Banjarsari & 14 & 100.0 \\
\hline
\end{tabular}

Referring to empirical data in the field and historical records of traditional markets in Surakarta, before the Keraton's relocation from Kartosura to Surakarta on 17 February 1745, there has been trading activities in the valley areas of Semanggi, Bengawan Solo and Pepe Rivers (Mutiari et al., 2010). Built in 1930, Gede Market is the oldest traditional market in Surakarta. It has been an economic center in the glory 
reign of Surakarta Hadiningrat Sunanate. It has even become a Chinese trading center before Keraton existed. In this era, there was a well-known Chinese merchant named Babah Mayor. Meanwhile, the largest market is Notoharjo Market $\left(17,276 \mathrm{~m}^{2}\right)$ built in 2006. Nevertheless, Klewer Market is the market having most occupied stalls (2,069 stalls). These facts portray that there is high interest to sell in a traditional market which is well-established and has uniqueness value, such as Klewer Market. The 43 traditional markets are classified based on Surakarta Mayor Decree No. 511.2/085 A/I/2001 regarding The Determination of Market Class and Basic Place Value Estimation. The presence of these markets is expected to give maximal contribution to society and the government of Surakarta.

\subsection{Commodity Variety of Traditional Market in Surakarta}

Along with lifestyle change, for instance the society's animo who prefer to shop and have recreation in mall, hence, traditional markets start to improve themselves by providing cleaner and more comfortable facility and goods completeness. Moreover, the government proposes Region Regulation to change the term Pasar Tradisional (Traditional Market) into Pasar Rakyat (Community Market) so that society does not feel that traditional markets are identical to conservatism. Furthermore, the more alarming view is that those who visit traditional markets only want to create a good image. Various service scopes available in the traditional markets in Surakarta can be examined from traditional markets' commodity variety in Surakarta in Table 3. This condition is not quite different from the research findings of Javalgi and Grossman (2016), Kim et al. (2004), Næss and Jensen (2004), Rahadi (2012), Wongleedee (2015), that traditional markets functions not only as selling-buying venue but beyond, it is related to life conception and socio-cultural interaction as well as recreation facility both in regional and urban scope.

According to the identification's result, the distribution and service scope of traditional markets showed an overlap between each market. It can be observed from Figure 8 that the existence of traditional market is centered on city center. The market having the largest service scope is Windujenar or Triwindu Market because it has the commodity of Javanese antiques. Meanwhile, the markets having national scope are Legi Market and Gede Market, regional scope are 15 markets, city scope are 14 markets, and local scope are 11 markets. Therefore, it can be concluded that market distribution does not rely on service scope standard, but rather natural growth of society needs. If it is connected to traditional urban space structure which is divided into four parts namely kutagara, nagaragung, mancanegara, and pesisiran, thus the current service scope is the transformation of service scope in the glory reign of Mataram Kingdom.

Figure 8. The spatial distribution of traditional markets' service scope in Surakarta (Analysis, 2015)

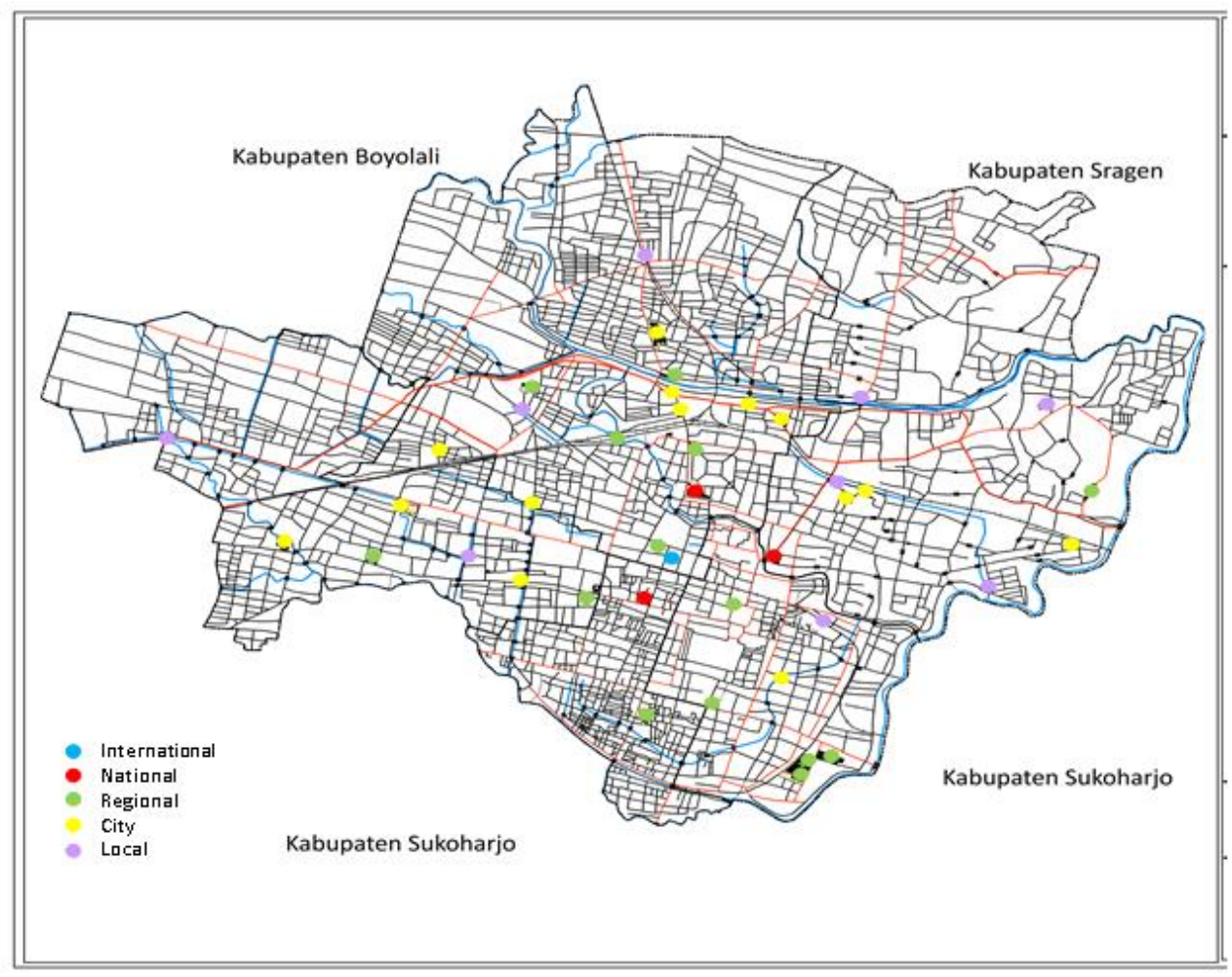


Table 3. Comodity and service scope classification of traditional market in Surakarta in 2016 (Analysis, 2016)

\begin{tabular}{|c|c|c|c|c|}
\hline No & Market & Commodity Specification & Operating Hours & Service Scope \\
\hline 1. & Legi & Crops & $00.00-24.00$ & National \\
\hline 2. & Klewer & Textile & $07.00-17.00$ & National \\
\hline 3. & Cinderamata & Textile souvenirs & $07.00-20.00$ & Regional \\
\hline 4. & Singosaren & Various & $07.00-14.00$ & Local \\
\hline 5. & Notoharjo & Snacks & $07.00-18.00$ & Regional \\
\hline 6. & Gede & Various & $00.00-24.00$ & National \\
\hline 7. & Nusukan & Various & $06.00-12.00$ & City \\
\hline 8. & Harjodaksino & Various & $02.00-11.00$ & Regional \\
\hline 9. & Jongke & Various & $06.00-17.00$ & City \\
\hline 10. & Rejosari & Various & $06.00-20.00$ & Local \\
\hline 11. & Turisari / Nongko & Various & $05.00-21.00$ & City \\
\hline 12. & Purwosari & Various & $06.00-17.00$ & City \\
\hline 13. & Sidodadi & Various & $05.00-11.00$ & Local \\
\hline 14. & Ledoksari & Various & $05.00-11.00$ & City \\
\hline 15. & Kadipolo & Various & $06.00-17.00$ & Regional \\
\hline 16. & Tanggul & Various & $06.00-11.00$ & Local \\
\hline 17. & Depok & Pet & $08.00-16.00$ & Regional \\
\hline 18. & Kabangan & Drum,Plastics & $06.00-17.00$ & Regional \\
\hline 19. & Penumping & Various & $06.00-11.00$ & Local \\
\hline 20. & Chicken & Chicken & $06.00-18.00$ & Regional \\
\hline 21. & Kliwon & Various & $05.00-11.00$ & City \\
\hline 22. & Jebres & Various & $05.00-11.00$ & City \\
\hline 23. & Kembang & Flowers & $06.00-17.00$ & City \\
\hline 24. & Ayu Balapan & Various, package, ticket & $00.00-24.00$ & Regional \\
\hline 25. & Proliman & Various & $07.00-17.00$ & Regional \\
\hline 26. & Furniture & Furniture & $00.00-24.00$ & City \\
\hline 27. & Windujenar & Antiques & $09.00-17.30$ & International \\
\hline 28. & Ngemplak & Various & $07.00-17.00$ & City \\
\hline 29. & Mojosongo & Various & $05.00-12.00$ & Local \\
\hline 30. & Bangunharjo & Various & $06.00-15.00$ & City \\
\hline 31. & Sidomulyo & Various & $08.00-12,00$ & City \\
\hline 32. & Gading & Various & $04.00-17.00$ & Regional \\
\hline 33. & Sangkrah & Various & $04.00-12.00$ & Local \\
\hline 34. & Tunggulsari & Various & $07.00-11.00$ & Local \\
\hline 35. & Jurug & Fruits & $06.00-10.00$ & Regional \\
\hline 36. & Ngumbul & Various & $07.00-09.00$ & Local \\
\hline 37. & Bambu & Bamboos, Logs & $07.00-16.00$ & Regional \\
\hline 38. & Iron & Iron & $08.00-17.00$ & Regional \\
\hline 39. & Joglo & Various & $05.00-13.00$ & Local \\
\hline 40. & Ngarsopuro & Electronics & $08.30-20.00$ & Regional \\
\hline 41. & Panggungrejo & Various & $06.00-20.00$ & Local \\
\hline 42. & Ngudi Rejeki Gilingan & Clothes, shoes, crafts, electronics, rings & $05.00-00.00$ & City \\
\hline 43. & Pucangsawit & Car wheels, jeans modification, food stalls & $06.00-20.00$ & City \\
\hline
\end{tabular}




\subsection{The Improvement of Spatial-Based Management of Traditional Markets in Surakarta}

The mapping's result of service scope spatial distribution of traditional markets in Surakarta signified that market distribution does not employ service scope standard established by Indonesian National Standard in the location of markets with local, city, regional, national, and international service scope. Spatial distribution is emphasized more on society needs which grow naturally. As a result, it brings positive effects on each market's development. Every market can grow and develop without worrying about competition with adjacent traditional market. As a matter of fact, competition happens and is felt by retailer markets of local service scope with adjacent mini-markets or modern retails. Nevertheless, markets of city, regional, national, and international service scope can survive in any situation. It is in line with what have been suggested by Zakariya \& Harun (2013) that the effort to revive historical space can be carried out by activating space surrounding historical site by temporary market activity. Thus, the activity between historical activity and daily activity can support cultural sustainability (Zakariya \& Harun, 2013).

Various problems of traditional markets in Surakarta are partly related to building's physical condition and social relationship among sellers. The government who has authority towards traditional markets' management and planning has done many attempts to improve management including (1) Spatial planning in traditional markets is done by a model of classification and separation for wet, semi-wet, and dry commodities and needs a planning based on the biggest seller to least seller level; (2) The circulation management of people, goods, and tools is used as the main consideration, since it will influence activity comfort in traditional markets; (3) The planning of healthy markets in the case of spatial and social relationship, for instance illegal stall's sellers whose merchandise should not block other sellers' merchandise; (4) The planning of similar merchandise type at one floor and inter-floor; (5) The management improvement with the existence of Standard Operating Procedure (SOP) for each market organizer. It is in accordance with Rahadi's research finding which reveals that in the case of traditional markets at micro level, factors such as service quality, increase in seller's number, and consumer identification play significant role to boost development and shopping activity escalation in traditional markets (Rahadi, 2012).

With the presence of those factors, hence, traditional markets in Surakarta at present can be labeled as traditional markets of character, meaning that every market has uniqueness and consumers that are not influenced by another closer market. Besides, every market supports and complements one another. It is in line with Sirait's research finding which suggests that market can be an indicator of change in production, consumption, and distribution of goods in a region (Sirait, 2006).

\section{CONCLUSION}

These finding shows that the distribution of traditional markets does not grow based on service scope or total number of market as suggested in Central Place Theory, but rather, based on natural growth of society needs. Regarding the traditional markets' management in Surakarta, the government as the authorities has carried out many efforts to improve management. These efforts are neither based on the amount of turnover, the number of sellers, nor the width of scope. Instead, it is emphasized more on commodity specification and visitors' characteristics.

\section{ACKNOWLEDGMENTS}

The researcher team expresses gratitude to Department of Urban and Regional Planning, Faculty of Engineering, Sebelas Maret University and Doctoral Program in Architecture and Urbanism, Diponegoro University who have facilitated in achieving doctorate scholarship from the Directorate General of Higher Education for funding this education and research. In addition, the researchers thank all of the parties who have contributed towards this research, specifically the Market Management Agency of Surakarta Government.

\section{REFERENCES}

Aliyah, I., Setioko, B., \& Pradoto, W. (2016). The Roles of Traditional Markets as the Main Component of Javanese Culture Urban Space (Object of Study: The City of Surakarta, Indonesia). The IAFOR Journal of Sustainability, Energy \& the Environment, 3(1), 103-120. 
Bae, S. H., \& Yun, H. J. (2017). Spatiotemporal Distribution of Visitors' Geotagged Landscape Photos in Rural Areas. Tourism Planning \& Development, 14(2), 167-180. [CrossRef]

Christaller, W. (1966). Central places in southern Germany. Prentice-Hall.

Eisner, S., Gallion, A., \& Eisner, S. (1993). The urban pattern. John Wiley \& Sons.

Ekomadyo, A. S. (2012). Menelusuri Genius Loci Pasar Tradisional sebagai Ruang Sosial Urban di Nusantara. Semesta Arsitektur Nusantara.

Jano, P., \& Mainville, D. (2006). Public and Private Roles in Promoting Small Farmers' Access to Nontraditional Markets: Case Studies from Central America.

Javalgi, R. (Raj) G., \& Grossman, D. A. (2016). Aspirations and entrepreneurial motivations of middle-class consumers in emerging markets: The case of India. International Business Review, 25(3), 657-667. [CrossRef]

Karnajaya, S. (2002). Pengaruh Pemindahan Lokasi Pasar Terhadap Morfologi Kota Studi Kasus: Kota Cepu Kabupaten Blora. Program Pasca Sarjana Universitas Diponegoro.

Kim, J. II, Lee, C. M., \& Ahn, K. H. (2004). Dongdaemun, a traditional market place wearing a modern suit: the importance of the social fabric in physical redevelopments. Habitat International, 28(1), 143-161. [CrossRef]

Lee, S. W., \& Roseman, C. C. (1997). Independent and Linked Migrants: Determinants of African American Interstate Migration. Growth and Change, 28(3), 309-334. [CrossRef]

Ling, X., \& Jin, W. (2010). Dynamic simulation on spatial structure of metropolitan commerce based on monopolistic competition model. Acta Geographica Sinica, 65(8), 938-948.

Mutiari, D., et al. (2010). Pengaruh politik terhadap arsitektur rumah China: Studi kasus Pecinan sekitar Pasar Gedhe Surakarta. Yogyakarta: Universitas Gadjah Mada.

Næss, P., \& Jensen, O. B. (2004). Urban structure matters, even in a small town. Journal of Environmental Planning and Management, 47(1), 35-57. [CrossRef]

Pamardhi, R. (1997). Planing for Traditional Javanese Markets in Yogyakarta Region. Sydney: University of Sydney.

Pothen, Z., \& Nuske, S. (2016). Automated Assessment and Mapping of Grape Quality through Image-based Color Analysis. IFAC-PapersOnLine, 49(16), 72-78. [CrossRef]

Rahadi, R. A. (2012). Factors Related to Repeat Consumption Behaviour: A Case Study in Traditional Market in Bandung and Surrounding Region. Procedia - Social and Behavioral Sciences, 36, 529-539. [CrossRef]

Schweizer, G. (1984). Traditional distribution systems under the influence of recent development processes: periodic markets in the Yemen Arab Republic as an Example. Applied Geography and Development, 24, 24-37.

Sirait, T. S. (2006). Identifikasi Karakteristik Pasar Tradisional Yang Menyebabkan Kemacetan Lalu-Lintas Di Kota Semarang. Semarang: Department of Urban and Regional Planning, Faculty of Engineering, Diponegoro University.

Tan, Y., Kwan, M.-P., \& Chai, Y. (2017). Examining the impacts of ethnicity on space-time behavior: Evidence from the City of Xining, China. Cities, 64, 26-36. [CrossRef]

Tang, B. (2017). Is the distribution of public open space in Hong Kong equitable, why not? Landscape and Urban Planning, 161, 80-89. [CrossRef]

Taubenböck, H., et al. (2017). Measuring morphological polycentricity - A comparative analysis of urban mass concentrations using remote sensing data. Computers, Environment and Urban Systems, 64, 4256. [CrossRef]

Wang, J., et al. (2016). Response of urban heat island to future urban expansion over the Beijing e Tianjin e Hebei metropolitan area. Applied Geography, 70, 26-36. [CrossRef]

Wongleedee, K. (2015). Marketing Mix and Purchasing Behavior for Community Products at Traditional Markets. Procedia - Social and Behavioral Sciences, 197, 2080-2085. [CrossRef]

Yan, R. (2008). Pricing strategy for companies with mixed online and traditional retailing distribution markets. Journal of Product \& Brand Management, 17(1), 48-56. [CrossRef]

Yu, A., \& Nguyen, B. (2015). Fairness management. In Ethical and Social Marketing in Asia (pp. 253-273). Elsevier. [CrossRef]

Zakariya, K., \& Harun, N. Z. (2013). The People's Dataran: Celebrating Historic Square as a Potential Temporary Market Space. Procedia - Social and Behavioral Sciences, 85, 592-601. [CrossRef] 